\title{
ROZUM W DEFENSYWIE. W NAWIAZZANIU DO ENCYKLIKI FIDES ET RATIO
}

W 2018 roku mija 20 lat od ogłoszenia przez Jana Pawła II encykliki Fides et ratio. Rocznice takie skłaniają do postawienia pytania, czy i jak dalece postulaty zawarte w tym dokumencie zostały zrealizowane; czy zaobserwować można jakiś postęp w dialogu pomiędzy wiarą i rozumem. Ja, niestety, istotnego postępu w tym względzie nie zauważyłem. Więcej nawet: uważam, że apel Jana Pawła II nabiera dziś jeszcze bardziej dramatycznego charakteru. Mam na myśli nie tylko wzajemne odniesienia pomiędzy filozofią i teologią, lecz także szerszy kontekst kulturowy i społeczny, w którym wciąż zauważyć można nieufność wobec zdolności i ambicji człowieka do szukania obiektywnej prawdy, wciąż panuje moda na antyintelektualizm. Rozum nadal jest w defensywie, może nawet głębszej niż 20 lat temu. Sądzę przy tym, że zawarta w encyklice diagnoza obserwowanego dziś kryzysu antropologicznego i kulturowego zasługuje na dopełniający komentarz. Warto w szczególności nawiązać do fragmentu papieskiego dokumentu wskazującego na to, że ów upadek zaufania do rozumu wynika między innymi z wcześniejszych nadużyć w jego używaniu, z nadmiaru pokładanej w nim nadziei. W pierwszej części poniższych rozważań na te właśnie ,grzechy rozumu” pragnę zwrócić uwagę, by następnie pokazać - nader szkicowo - jak widzę ów kryzys zaufania do rozumu w samej filozofii, w teologii oraz w życiu społecznym. W konkluzji spróbuję jednak wskazać na pewne 
podstawy do ostrożnego optymizmu, do nadziei, że rozum może z tej defensywy wyjdzie zwycięsko.

Do takiej szerzej zakrojonej refleksji nad współczesną kondycją rozumu, dotykającej także jego roli w życiu społecznym, zachęca sam Autor encykliki. Bo choć jest ona oficjalnie adresowana „do biskupów Kościoła katolickiego” i choć mowa jest w niej nade wszystko „o relacjach między wiarą a rozumem”, to już w jej „Wprowadzeniu” Papież szkicuje najpierw wizję człowieka jako tego, kto „w ciągu stuleci przebył pewną drogę, która prowadziła go stopniowo do spotkania z prawdą i do zmierzenia się z nią"", następnie podkreśla doniosłą rolę filozofii w dociekaniu prawdy o świecie i o samym człowieku, a w dalszych partiach encykliki szeroko i wnikliwie omawia kryzys współczesnej filozofii, zwracając między innymi uwagę na zgubne dla życia społecznego jego efekty².

\section{POSTMODERNIZM: ZWĄTPIENIE W AUTORYTET I MOC ROZUMU}

Początek dramatycznego rozchodzenia się dróg wiary i rozumu Papież dostrzega nade wszystko u schyłku Średniowiecza, kiedy doszedł do głosu przesadny racjonalizm coraz bardziej przeciwstawiający rozum wierze, aż po wypracowanie różnych form ateistycznego humanizmu, które to formy „stały się podstawą programów społecznych i politycznych, prowadzących do powstania systemów totalitarnych, które przysporzyły ludzkości wielu cierpień"’3. Zaś w obszarze badań przyrodniczych dominować zaczęła mentalność pozytywistyczna, rezygnująca z wszelkich aspiracji metafizycznych i odniesień moralnych. Konsekwencją tego kryzysu racjonalistycznego jest, zdaniem Autora encykliki, nihilizm każący wątpić w samą możliwość poznania prawdy4. Te „grzechy rozumu” nie zostały do

\footnotetext{
1 Ja n P aw e 1 II, encyklika Fides et ratio, nr 1.

2 Por. tamże, zwł. nr. 45-48 oraz 81-91.

3 Tamże, nr 46.

4 Tamże.
} 
dziś przezwyciężone, choć przybrały nieco inną postać. Papież docenia doniosłość wielu filozoficznych dociekań, niepokoi się jednak takimi nurtami myślowymi, jak eklektyzm, historyzm, scjentyzm i pragmatyzm, prowadzące do umocnienia wspomnianego nihilizmu, który „nie tylko pozostaje w sprzeczności z wymogami i treścią słowa Bożego, ale przede wszystkim jest zaprzeczeniem człowieczeństwa człowieka i samej jego tożsamości"s. Znamienne jednak, że tę krytyczną refleksję nad współczesną filozofią Jan Paweł II kończy uwagami dotyczącymi postmodernizmu. Pisze tak: „Nasza epoka została określona przez niektórych myślicieli mianem »epoki postmodernizmu «", który jest czymś więcej, niż nurt myśli filozoficznej, choć na niej także odcisnął silne piętno. „Termin ten, stosowany często w bardzo różnych kontekstach, wskazuje na pojawienie się całego zespołu nowych czynników, których oddziaływanie jest tak rozległe i silne, że zdołało wywołać istotne i trwałe przemiany"7. Autor encykliki ostrożny jest w całościowej ocenie postmodernizmu, zaznacza jednak, że odwołując się do niego, niektórzy myśliciele głoszą, iż „epoka pewników minęła bezpowrotnie, a człowiek powinien teraz nauczyć się żyć w sytuacji całkowitego braku sensu, pod znakiem tymczasowości i przemijalności"8, a to oznacza kolejne wzmocnienie nastrojów nihilistycznych. Papież przyznaje jednak, że „,nihilizm ten znajduje swego rodzaju potwierdzenie w straszliwym doświadczeniu zła, jakie dotknęło naszą epokę. W obliczu tego doświadczenia załamał się racjonalistyczny optymizm, który odczytywał historię jako zwycięski pochód rozumu, źródła, szczęścia i wolności"”.

Otóż sądzę, że tu właśnie Papież wskazał na szczególnie silne i moralnie doniosłe źródła fali irracjonalizmu, która objęła nie tylko myśl filozoficzną, ale całą kulturę i życie społeczne. Jak trafnie ujmuje to Janusz Filipkowski, istotą postmodernizmu jest „krytyka

\footnotetext{
5 Tamże, nr 90.

6 Tamże, nr 91.

7 Tamże.

8 Tamże.

9 Tamże.
} 
modernizmu oraz związanego z nim oświeceniowego racjonalizmu" a wyrasta ona ,ze świadomości załamania się ideologii nowoczesności, z charakterystyczną dla niej wiarą w nieuchronność postępu oraz możliwość racjonalnego poznania i uporządkowania świata"10. Ten kryzys kojarzonego z Oświeceniem modernizmu zapoczątkowany został w dziedzinie sztuki już u końca XIX wieku, dla nas ważne jest jednak głównie rosnące w społeczeństwie europejskim rozczarowanie dotyczące oświeceniowego przekonania o wewnętrznym związku między wolnością a rozumem. Filipkowski cytuje opinię Ch.W. Millsa, którego zdaniem ,wzrost racjonalizmu nie tylko nie wpłynął na wzrost poziomu indywidualnej wolności, lecz przyniósł ze sobą pojawienie się społeczeństwa »szczęśliwych robotów«, które pożądają niewoli i same chętnie stają się niewolnikami" "ll.

$\mathrm{Na}$ to nałożyły się doświadczenia dwóch wojen światowych i chyba do nich nawiązuje Papież w ostatnio cytowanym fragmencie encykliki. Zygmunt Bauman idzie dalej. W książce Nowoczesność i Zagłada (ze znamiennym podtytułem: Holokaust - choroba czy produkt cywilizacji?) podkreśla, iż ,zagładę obmyślono i przeprowadzono w naszym nowoczesnym racjonalnym społeczeństwie, w zaawansowanym stadium jego cywilizacyjnego rozwoju, w szczytowej fazie rozkwitu naszej kultury i dlatego Zagłada jest problemem tej cywilizacji i tej kultury"'2. Bauman nie twierdzi, iż do Zagłady musiało dojść; przekonuje natomiast, że nie jest to problem wyłącznie żydowski ani niemiecki (co by pozwalało poprzestać na uznaniu jej za wyjątkowe wydarzenie, które oby się nigdy nie powtórzyło), ale jest to dowód (nie jedyny zresztą) przemawiający za ambiwalencją naszej nowoczesnej, zracjonalizowanej cywilizacji, w której głosi się szczerze wiele wzniosłych haseł, buduje się wiekopomne dzieła kultury - a zarazem doskonali się racjonalne mechanizmy

${ }^{10}$ J. Fili p k o w s k i, hasło „Modernizm” w: Encyklopedia katolicka, t. XVI, Lublin 2012, szp. 73. Całe to hasło znakomicie przybliża sens tego terminu oraz rozliczne sfery jego oddziaływania.

11 Por. tamże, szp. 74.

12 Z. B a u m a n, Nowoczesność i Zagłada, tłum. T. Kunz, Kraków 2009, s. 13. 
usprawniające dokonywanie okrucieństw - i to w świetle prawa, nierzadko z szeroką ich społeczną aprobatą. Trudno nie przywołać tu słów George'a Orwella, które Bauman cytuje na początku swej książki: „Podczas gdy piszę te słowa, nad moją głową latają kulturalni ludzie, którzy próbują mnie zabić. Nie odczuwają wobec mnie żadnej wrogości, ani ja wobec nich. »Spełniają jedynie swój obowiązek». Większość z nich to bez wątpienia dobrzy i posłuszni prawu obywatele, którym nie przeszłoby przez myśl, żeby popełnić morderstwo w prywatnym życiu. Jeżeli jednak któremuś z nich uda się rozerwać mnie na strzępy za pomocą celnie zrzuconej bomby, nie będzie przez to spał ani odrobiny gorzej - służy bowiem swojemu krajowi, a ten władny jest oczyścić go z grzechu"13.

Oto więc surowe oskarżenie modernizmu i stanowiącego jego sedno zaufania do rozumu. Modernizm zacieśnia pojmowanie człowieka i jego twórczości (to nie przypadek, że postmodernizm zrodził się najpierw w dziedzinie sztuki), wprowadza dominację ,,konsumpcyjnego, stechnicyzowanego i zunifikowanego stylu życia"14, uruchamia mechanizmy społeczne otwierające drogę do wojny, Zagłady i innych okrucieństw, które znakomicie mieszczą się w modernistycznym porządku cywilizacyjnym. Cóż dziwnego, że rozczarowanie nadziejami Oświecenia, a bardziej jeszcze wydarzenia dwóch wojen światowych, podważyły zaufanie do rozumu i jego kierowniczej roli w budowaniu kultury oraz porządku życia społecznego!

To oskarżenie jest poważne i nie wolno go ignorować. Ale odnosi się ono do określonej, nader zredukowanej funkcji rozumu; do jego służebnej roli w budowaniu nowoczesnej cywilizacji. Nie o taki sens rozumu dopominał się Papież w swej encyklice. Jemu chodziło o rozum jako umysłową władzę daną człowiekowi po to, by szukał prawdy i by ją - odkrywszy - kontemplował. Owszem, rozum potrzebny jest także do budowania życia społecznego, ale ma to być życie rozumnych, kochających i twórczych osób ludzkich, poszukujących sensu swego życia, otwartych na rzeczywistość

\footnotetext{
13 Tamże, s. 5.

14 J. Fil li p k o w s k i, hasło „Postmodernizm”, dz. cyt., szp. 73.
} 
przekraczającą doczesny wymiar zmysłowych doznań, upatrujących w rozumie drogę do osiągnięcia mądrości. Dlatego Papież tak usilnie wzywa filozofów, by nie rezygnowali z pytań „o zasięgu prawdziwie metafizycznym", otwierającym ludzki umysł także do poznania istoty dobra moralnego, którego respektowanie i realizowanie wyznacza drogi sensownego życia ${ }^{15}$. Czy filozofowie podjęli to wyzwanie?

\section{FILOZOFIA - NADAL MINIMALISTYCZNA}

Wspomniany postmodernizm obecny jest oczywiście także we współczesnej filozofii. J. Derrida, M. Faucault, R. Rorty i szereg innych filozofów odrzuca oświeceniowy racjonalizm, w tym zwłaszcza kult obiektywnej prawdy („logocentryzm”) prowadzący, ich zdaniem, do tworzenia całościowych systemów filozoficznych, roszczących pretensje do obiektywnego prezentowania rzeczywistości, co prowadzi do „kulturowego uniformizmu oraz opresywnych wizji społeczeństwa, sankcjonujących przemoc społeczną w imię prawd, które uznawane są za obiektywne i absolutnie prawdziwe"16. Sprzeczność pomiędzy takimi poglądami a apelami zawartymi w encyklice jest oczywista i nie trzeba jej chyba dalej komentować. Papież zdecydowanie nie uważa, by uczciwe poszukiwanie prawdy musiało prowadzić do tak zgubnych dla człowieka konsekwencji.

Ale współczesna filozofia nie sprowadza się do postmodernizmu, trudno nawet uznać go za nurt wiodący. Dziś w filozofii dominującą rolę odgrywa raczej filozofia analityczna, silnie opozycyjna w stosunku do postmodernizmu. Kładzie ona nacisk właśnie na jasność myślenia i precyzję wypowiedzi, na adekwatne uzasadnienie głoszonych tez, jest nasycona logiczną kulturą. Respekt dla rozumu i jego autorytetu jest w niej szczególnie mocno akcentowany i propagowany. Osiągnięcia tej filozofii są znaczne i manifestują one raczej kult rozumu, a nie podważanie jego autory tetu. Z pewnością jednak filozofia analityczna nie rości sobie ambicji do podejmowania wielkich

\footnotetext{
15 Por. Ja n Paweł I I, dz. cyt., nr 83.

16 J. Fili p k ow s k i, hasło „Modernizm”, art. cyt., szp. 74.
} 
wyzwań metafizycznych. Raczej przeciwnie, programowo koncentruje się na analizie języka potocznego, szukając w nim ważnych intuicji filozoficznych. Owszem, analizy te owocują interesującymi wynikami dotyczącymi mentalności człowieka: stylu jego myślenia, sensu formułowanych przez niego twierdzeń itp.- ale daleko jej do stawiania pytań o sens ludzkiego istnienia, o perspektywę metafizyczną sięgającą poza zakres potocznych intuicji, trudnych do jednoznacznego i usystematyzowanego opracowania. Tadeusz Szubka, znakomity znawca filozofii analitycznej, podkreśla, że „najbardziej widocznym ograniczeniem [tej filozofii - przyp. A.Sz.] jest hołdowanie ideałom scjentyzmu i ahistoryzmu. [...] Jeżeli dodać do tego rozmaite i dogmatyczne odmiany naturalizmu metafizycznego, przyjmowane często jako coś, co nie podlega dyskusji, nie powinno dziwić, że filozofia analityczna zdradza niekiedy oznaki degenerującego programu badawczego"'17.

Nurtów filozofii współczesnej jest oczywiście znacznie więcej, trudno je tu w miarę kompletnie wyliczyć. Ale albo mieszczą się one w kręgu filozofii idealistycznej, skupionej raczej na jego strukturach poznawczych, kwestionujących zdolność dotarcia do obiektywnej prawdy (neokantyzm, fenomenologia), albo koncentrują się jedynie na relacji pomiędzy człowiekiem a innymi ludźmi i otaczającym światem (filozofia dialogu), albo wreszcie analizują mechanizmy budowania struktur społecznych (strukturalizm, także marksizm). Owszem, do kontynuowanych dziś nurtów filozoficznych należy też neotomizm - i Jan Paweł II podkreślał w encyklice wielkie znaczenie filozofii św. Tomasza z Akwinu, ale nie widać, by inspiracja encykliki poważnie wpłynęła na rozwój filozofii inspirowanej myślą Akwinaty.

W związku z tomizmem warto dodać jeszcze jedną uwagę. Otóż zarówno Arystoteles, do którego z aprobatą odnoszą się liczni tomiści, jak i sam św. Tomasz z Akwinu, jak wreszcie wielu innych filozofów (zwłaszcza Immanuel Kant) budowali swe systemy filozoficzne uwzględniając stan ówczesnej wiedzy o świecie, o człowieku

${ }^{17}$ T. S z u b k a, Filozofia analityczna. Koncepcje, metody, ograniczenia, Wrocław 2009, s. 230. 
i otaczającej go przyrodzie. Czy współczesny neotomizm idzie tą samą drogą? Chyba nie. Jego wpływowi przedstawiciele bronią raczej odrębności filozofii wobec nauk empirycznych, podkreślając znaczenie podstawowego, przednaukowego doświadczenia (zdrowego rozsądku). Pisze M. Albert Krąpiec: „Nauki szczegółowe wychodzą tylko z pewnych danych zdrowego rozsądku, a nie obejmują całokształtu właściwej mu dziedziny. [...] Filozofia natomiast, badając całą rzeczywistość (byt- jako - istniejący) zarówno będącą nami, jak i nas otaczającą, wyznacza sobie przez to szeroki zakres badań. [...] Filozofia ustalając dla siebie przedmiot obiera także dostosowaną do tak szerokiego zakresu badań swoistą metodę, różną od metody nauk szczegółowych"18. Obawiam się, że nacisk położony na odrębność filozofii bytu od nauk szczegółowych spowodował wyjałowienie myśli filozoficznej kultywowanej w duchu św. Tomasza z Akwinu. Nie studiowałem pilnie tomistycznych dzieł powstałych w ostatnim dwudziestoleciu, ostrożnie się więc w tej materii wypowiadam, ale nie odnotowałem żadnej inspiracji płynącej z osiągnięć nauk szczegółowych, prowadzącej do rewizji założeń lub niektórych tez filozofii neotomistycznej - choć uczeni, zwłaszcza kosmologowie i biolodzy, stawiają coraz częściej pytania filozoficznie doniosłe. Nauki te, wedle mojej wiedzy, nie poddają się modzie postmodernistycznej; tam na ogół rzetelnie poszukuje się prawdy obiektywnejale trudno powiedzieć, by wyniki prowadzonych przez nich badań istotnie wpływały na rozwój filozofii bytu. W jej relacji z naukami szczegółowymi (zwłaszcza przyrodniczymi) wciąż podkreśla się odrębność przedmiotu i zakresu tych badań, co dialogowi filozofii bytu ze światem nauki zdecydowanie nie sprzyja. Owszem, ks. prof. Michał Heller podjął inicjatywę takiego dialogu, założył nawet serię książek zatytułowaną „Zagadnienia filozoficzne w nauce”, nie jest on jednak z pewnością neotomistą.

W filozofii nie znajduję więc żadnych oznak świadczących o przejęciu się apelem Papieża o podjęcie wielkich pytań metafizycznych. Podejmują je wprawdzie kontynuatorzy myśli św. Tomasza z Akwinu,

18 M. A. K r ą p i e c, Realizm ludzkiego poznania, Lublin 1995, s. 50. 
ale czynią to tak, jak czynili przed opublikowaniem encykliki Fides et ratio, a ten nurt filozofii trudno uznać za główny nurt filozofii współczesnej. Raczej panuje w niej więc nadal swoisty ,antymetafizyczny minimalizm", z silną domieszką sceptycyzmu podważającego zdolność ludzkiego umysłu do poznania obiektywnych i ważnych dla człowieka prawd o nim samym, o świecie i o Bogu. Jest to, jak pisze Papież, ,postawa głębokiej nieufności wobec rozumu, dostrzegalna w najnowszych postaciach wielu nurtów refleksji filozoficznej”. $\mathrm{W}$ tym sensie wciąż w filozofii rozum jest w defensywie.

\section{TEOLOGIA: OTWARTA NA FILOZOFIĘ I OSIĄGNIECCIA NAUK? ${ }^{19}$}

W roku 1879 papież Leon XIII ogłosił encyklikę Aeterni Patris, w której wezwał katolickich uczonych do powrotu do filozofii św. Tomasza z Akwinu. Jak przypomina Jan Paweł II, było to wydarzenie wręcz przełomowe w życiu Kościoła. Rozpoczęły się studia nad myślą Akwinaty, rozmachu nabrały badania historyczne, powstały nowe szkoły tomistyczne. Odrodzenie tomizmu miało przy tym dość trwały charakter. „Najbardziej wpływowi teolodzy naszego stulecia, których przemyślenia i poszukiwania stały się ważną inspiracją dla Soboru Watykańskiego II, zostali ukształtowani przez ten ruch odnowy filozofii tomistycznej" ${ }^{20}$. Czy encyklika Fides et ratio spotkała się z podobnie gorliwą mobilizacją katolickich uczonych? Chyba nie. Owszem, trzeba pamiętać, że o ile Leon XIII wskazał na samego św. Tomasza z Akwinu jako przewodnika w odrodzeniu filozofii (a z jej pomocą także teologii katolickiej), o tyle św. Jan Paweł II, choć dał w swej encyklice wyraz wielkiego uznania dla myśli Akwinaty podkreślając jej nieprzemijającą nowość ${ }^{11}$, to jednak dopuścił możliwość rozwijania innych nurtów filozoficznych, wskazując zarazem,

\footnotetext{
19 Ja n P aw eł II, dz. cyt., nr 55.

20 Tamże, nr 58.

21 Por. tamże, nr. 43-44.
} 
jakimi walorami winne się one wyróżniać, by mogły być pomocne w pogłębieniu wiary i w rozwoju teologii ${ }^{22}$.

Ale apel Papieża jest wyraźny: istotnym, choć trudnym zadaniem teologii jest ,zrozumienie prawdy objawionej, czyli wypracowanie intellectus fidei. [...] Jeżeli intellectus fidei ma ogarnąć całe bogactwo tradycji teologicznej, musi odwoływać się do filozofii bytu”. Podkreślić warto znamienne zastrzeżenie Papieża: „Filozofia ta winna być w stanie sformułować na nowo problem bytu zgodnie z wymogami i dorobkiem całej tradycji filozoficznej, także nowszej, unikając powielania przestarzałych schematów”23. I dalej: „Podobny wywód można przeprowadzić również w odniesieniu do teologii moralnej”. Przypomniawszy wyrażone w encyklice Veritatis splendor niepokoje dotyczące rozwijanego przez niektórych teologów nowego rozumienia sumienia, przyznającego mu ,przywilej autonomicznego określania kryteriów dobra i zła”24, Papież przypomina: „W całej Encyklice podkreśliłem wyraźnie podstawową rolę prawdy w dziedzinie moralności”. W związku z tym dla wypełnienia właściwej sobie misji „teologia moralna winna posłużyć się etyką filozoficzną, która odwołuje się do prawdy o dobru, a więc nie jest ani subiektywistyczna, ani utylitarystyczna". Wreszcie Jan Paweł II zwraca uwagę na znaczenie formacji filozoficznej w głoszeniu wiary i w katechezie podkreślając, iż „wzajemna więź, jaka powstaje między dyscyplinami teologicznymi a poglądami wypracowanymi przez różne nurty filozoficzne, może się [...] okazać naprawdę przydatna w dążeniu do przekazania wiary i do jej głębszego zrozumienia"25. W tym kontekście nie dziwią słowa Papieża: „Pragnę stanowczo potwierdzić, że studium filozofii jest podstawowym i nieodzownym elementem w strukturze studiów teologicznych i w formacji kandydatów do kapłaństwa". Nie dziwi też

22 Por. tamże, nr. 75-85.

23 Tamże, nr 97.

24 W rozprawie Natura - rozum - wolność, Rzym 1990, pozwoliłem sobie określić ten pogląd mianem koncepcji twórczego rozumu. Stąd podtytuł książki: Filozoficzna analiza twórczego rozumu we współczesnej teologii moralnej. Por. zwł. tamże, s. 248-289.

25 J a n Paweł I I, dz. cyt., nr. 97-99. 
jego niepokój, iż obserwowane ostatnio pomniejszenie roli filozofii w seminariach duchownych rodzi „,brak zainteresowania współczesną myślą i kulturą, który prowadzi do zaniku jakichkolwiek form dialogu lub też do bezkrytycznego przyjmowania wszelkich poglądów filozoficznych" ${ }^{26}$.

Czy ten stanowczy apel Papieża znalazł wyraz w rekonstrukcji programu studiów teologicznych, a zwłaszcza seminaryjnych? Wątpię. Tradycyjnie określa się pierwsze dwa lata edukacji seminaryjnej jako „filozofię”, po której następują kolejne cztery lata studiów teologicznych. Ale już w czasie moich studiów seminaryjnych (początek lat 70. ubiegłego stulecia) przedmioty filozoficzne obejmowały mniej niż połowę zajęć przewidzianych na pierwsze dwa lata studiów. A dziś? Policzyłem liczbę godzin przedmiotów filozoficznych w ramach pierwszych dwóch lat studiów seminaryjnych na KUL w roku 2016/2017. Otóż na łączną liczbę 1170 godzin, dla przedmiotów filozoficznych zarezerwowano 390 godzin, czyli dokładnie 1/3 całej puli wykładowo-ćwiczeniowej (a 360 godzin na wykłady już wprowadzające do teologii). W ciągu kolejnych czterech lat nie przewiduje się dalszej edukacji filozoficznej. Podkreślam to, ponieważ edukacja ta nie jest łatwa, trudno oczekiwać od studentów pierwszych dwóch lat zrozumienia meandrów myśli kantowskiej lub postmodernistycznej. Czy nie można by więc zarezerwować jakiejś puli zajęć z filozofii na ostatnim roku studiów, tuż przed rozpoczęciem pracy duszpasterskiej? Oczywiście, przyjęty na KUL program studiów respektuje wymogi stosownego ratio studiorum, ale czy encyklika Fides et ratio nie podpowiada, by te wymogi przemyśleć? W efekcie absolwenci studiów teologicznych kończą studia bardzo słabo (jeśli w ogóle) przygotowani do dialogu z panującymi dziś prądami myśli kulturowej, do podejmowania ważnych dziś filozoficznych zagadnień, do dyskusji z tymi nurtami myślowymi, które dalekie są od chrześcijańskiej wizji człowieka, świata i Boga. Nawet pobieżna obserwacja aktywności duszpasterskiej naszych księży (zwłaszcza homilii) zdaje się potwierdzać opinię, że więcej w nich emocji, niż

26 Tamże, nr 62. 
wrażliwości na rozpowszechnione trendy myślowe, zasługujące na rzetelną nad nimi refleksję i ukazywanie na ich tle wartości chrześcijańskiego Objawienia.

A chodzi nie tylko o żywy kontakt ze współczesną filozofią. Dziś modne jest hasło, iż budujemy ,społeczeństwo wiedzy”. Wiedza ta nie ogranicza się do sfery dociekań filozoficznych; łatwo dostępne media informują o coraz to nowych osiągnięciach nauk przyrodniczych i humanistyczno-społecznych, stanowiących często niemałe wyzwanie także dla teologii i duszpasterzy. W książce Nowa fizyka i nowa teologia ks. Michał Heller postuluje nawet mecenat Kościoła nad placówkami badawczymi podejmującymi problemy z zakresu genetyki, biologii molekularnej i im podobnych, ponieważ ,stawiają one przed ludzkością wiele problemów etycznych, których samo zrozumienie, a tym bardziej właściwa ocena, wymaga głębokich studiów”. I dodaje: „W seminariach duchownych i innych instytucjach kościelnych można by wprowadzić przedmioty bardziej związane z naukami przyrodniczymi, takie jak na przykład, filozofia i historia nauki czy zagadnienia dotyczące problemu »nauka a wiara«. W obecnym systemie kształcenia przyszłych duchownych wciąż jeszcze polemiki z herezjami z pierwszych wieków chrześcijaństwa zajmują więcej miejsca niż przygotowanie intelektualne do przyszłej pracy duszpasterskiej w świecie kształtowanym przez nauki przyrodnicze"27.

To są jednak tylko, jak dotąd, piękne postulaty. Chciałbym bardziej być większym optymistą, ale moim zdaniem, pomimo upływu 20 lat od opublikowania omawianej tu doniosłej encykliki, teologowie nie przejęli się zbytnio wezwaniem do pogłębionego dialogu ze współczesną filozofią oraz osiągnięciami nauk szczegółowych, encyklika ta nie wpłynęła też na reformę studiów teologicznych, zwłaszcza

${ }_{27}$ M. H e 11 e r, Nowa fizyka i nowa teologia, Kraków 2014, s. 36. Spośród innych publikacji ks. Hellera na szczególne wyróżnienie, w kontekście podejmowanych tu rozważań, zasługuje pozycja Sens życia $i$ sens wszechświata. Studia z teologii współczesnej (Kraków 2014), gdzie szczególnie wnikliwie omawia Autor rolę filozofii w dialogu pomiędzy teologią a naukami szczegółowymi. 
seminaryjnych. Ani panujące dziś nurty filozoficzne, ani wyzwania współczesnej nauki, która - raz jeszcze to podkreślam - respektuje w swoim zakresie wymóg racjonalnego poszukiwania obiektywnej prawdy, nie pobudziły teologów do reakcji, do której tak usilnie zachęcał Jan Paweł II. Także tu więc rozum pozostaje w defensywie.

\section{ANTYINTELEKTUALIZM DYSKURSU PUBLICZNEGO}

Pesymizm mój jest jeszcze większy, gdy myślę o stylu, w jakim prowadzony jest w Polsce - i nie tylko w Polsce - dyskurs publiczny, zwłaszcza polityczny. Prof. Kazimierz Twardowski, potocznie uważany za ojca wielce zasłużonej dla filozofii Szkoły Lwowsko-Warszawskiej, wygłosił - z okazji przyznania mu w 1932 roku doktoratu honoris causa na Uniwersytecie Poznańskim - piękny odczyt „O dostojeństwie uniwersytetu”. Podkreślając doniosłość i pożytek płynący z respektowania właściwej etosowi uniwersytetu kultury prowadzenia sporów, mówił między innymi: „Tak samo, jak wyniki badań naukowych uwalniają nas coraz skuteczniej od niedomagań cielesnych, tak też cały szereg utrapień moralnych, dręczących ludzkość, znikłby lub doznałby znacznego złagodzenia, gdyby zechciano się niemi zająć ze stanowiska prawdy objektywnej. Ileż to nienawiści, dzielącej ludzkość na zwalczające się namiętnie obozy, straciłoby grunt pod nogami, gdyby usiłowano będące zarzewiem tej nienawiści kwestye sporne rozpatrywać sposobami naukowemi! Albowiem wtedy albo udałoby się kwestye te rozstrzygnąć objektywnie, albo przekonanoby się, że różne krzyżujące się zdania są w równej mierze pozbawione uzasadnienia, że więc żadne z nich nie ma prawa żądać dla siebie posłuchu. Tak więc prawda objektywna a nawet samo rzetelne dążenie do niej wnosi ukojenie w spory i walki przeciwnych sobie poglądów i usuwając to, co ludzi przeciw sobie podnieca, daje im to, co ich godzi i nastraja ku sobie życzliwie. Tym sposobem służenie prawdzie objektywnej nabiera znaczenia etycznego i stawać się może w stopniu coraz wyższym prawdziwym błogosławieństwem 
ludzkości"28. Czytany dziś ten tekst budzi wzruszenie, któremu towarzyszy poczucie, że ten wielki uczony okazał tu niezmierną naiwność. Już przed wojną dyskurs polityczny daleki był od tych uniwersyteckich ideałów, a cóż powiedzieć, jeśli się je odniesie do dziś toczonych sporów publicznych?

Zatrzymuję się na polskim przykładzie, ponieważ ten znam lepiej niż debaty publiczne toczone w innych krajach. Nie wiem więc, czy i jak dalece jest tam podobnie, jak u nas. Ale już nasz polski przykład napawa wielkim niepokojem i skłania do opinii, że rozum, wraz z właściwym mu poszukiwaniem obiektywnej prawdy, został z dyskursów publicznych dość stanowczo wygnany. Przeciwnicy polityczni notorycznie oskarżają się o niecne intencje, co - gdy się chwilę zastanowić - podważa sens jakiegokolwiek politycznego dyskursu. Ten bowiem zakłada właśnie dobrą wolę strony przeciwnej, która wprawdzie inaczej widzi drogę do rozwiązania problemów, ale której zależy - podobnie jak nam - na znalezieniu jak najsprawiedliwszego rozwiązania konfliktu. Z człowiekiem złej woli się walczy, a nie dyskutuje (ewentualnie zachęca się go do zmiany postawy moralnej). Imputowanie przeciwnikom politycznym złej woli adresowane jest nie do nich, ale do opinii publicznej w nadziei, że w ten sposób oskarżyciel uzyska poparcie w kolejnych politycznych wyborach. Ale uwaga: to przecież oznacza, że ów oskarżyciel liczy na podobną, pozaracjonalną reakcję społeczeństwa. I, niestety, liczy dobrze. Internet pełen jest obrzydliwych, pełnych wulgaryzmów, bezpodstawnych oskarżeń i wyzwisk. To nasz - już nie polityków - irracjonalizm. Jeśli dobrze rozumiem przykazanie „Nie mów fałszywego świadectwa przeciw bliźniemu swemu", to kryje się w nim między innymi zakaz formułowania takich nieuzasadnionych publicznych oskarżeń. Gwoli przykładu można podać, że w trakcie tegorocznych (2017) obchodów rocznicy Sierpnia 1980 (obchodów - jak to się dzieje od lat - świadczących o podziałach społecznych, a nie o narodowej solidarności), członkowie i sympatycy jednej z oragnizacji zostali

${ }^{28}$ K. Tw a r d ow s k i, O dostojeństwie uniwersytetu, Poznań 1933, s. 7. Zachowuję oryginalną, dziś już przestarzałą pisownię. 
publicznie oskarżeni o to, że ich demonstracja była odgórnie zorganizowana i przez kogoś finansowana. Nie przedstawiono na to żadnych dowodów. Również w Sejmie zdarza się, że przeciwnicy polityczni określani są mianem zdrajców, morderców itp. Listę przykładów można by kontynuować ${ }^{29}$. Od dawna żywię przekonanie, że najbardziej ignorowanym i lekceważonym przykazaniem Dekalogu jest przykazanie ósme. Co w efekcie mamy? Społeczeństwo głęboko podzielone i skłócone; niechętne - a nie wiem, czy jeszcze w ogóle zdolne - do szukania dróg wzajemnego porozumienia. To przykre i upokarzające, ale polskie doświadczenia ostatnich lat stanowią znakomitą, choć dla nas bolesną, ilustrację konsekwencji odejścia od kierowania się rozumem w życiu społecznym, o których wspomina Papież w swej encyklice ${ }^{30}$.

Mówię o tym, ponieważ w tej nieufności wobec elit widzę jeszcze jedną oznakę nieufności i podejrzliwości wobec tych, którzy chcą w życiu osobistym i publicznym kierować się rozumem. Powszechnie wiadomo, że łatwiej grać na emocjach i nimi manipulować, niż

29 Wspomnieć tu muszę o jeszcze jednej sprawie. Obok znanego nam już podziału obywateli naszego kraju na prawdziwych i nieprawdziwych Polaków, pojawił się ostatnio nowy podział - a to w związku z planowaną przez Pana Prezydenta debatą na temat zmian w dotychczas obowiązującej Konstytucji RP. Usłyszeliśmy z ust Pana Prezydenta, a także innych polityków dziś Polską rządzących, że potrzebna jest publiczna debata, której efektem ma być nowa Konstytucja RP, która będzie „nie dla elit”, ale dla zwykłych obywateli. Kim są członkowie owych elit? Spontanicznie skłonni bylibyśmy uważać za elitę społeczeństwa głównie tych właśnie, którzy w wyniku wyborów demokratycznych rządzą krajem. Ale skoro to oni właśnie od nich się dystansują, to znaczy, że napiętnowana elita to inna grupa ludzi. Zapewne nie prości robotnicy i chłopi; ani oni sami do miana członków elity się nie zaliczają, ani inni ich tak nie traktują. Więc chyba intelektualiści, którzy dbają tylko o własne interesy, ignorując prawa i potrzeby ,zwykłych obywateli”? Trudno tu nie przypomnieć, że to w okresie komunizmu - zdawałoby się, bezpowrotnie minionym - przeciwstawiano „lud pracujący miast i wsi” inteligencji, których członków nawoływano (a niekiedy zmuszano), by wzięli do rąk łopaty i podjęli robotniczą pracę, a nie spędzali czasu na jałowych, nikomu nie przydatnych, intelektualnych rozważaniach. Polską rządziła wówczas Polska Zjednoczona Partia Robotnicza, a nie elity.

30 J a n P aw e 1 II, dz. cyt., nr 89. 
rządzić społeczeństwem ludzi rozumnych, myślących. Nie dziwi więc, że politycy takie pozaracjonalne struny w nas poruszają, niepokoi jednak bardzo skuteczność takich manipulacji. Skuteczność ta zdaje się pokazywać, jak głęboki kryzys dotknął naszą racjonalność, jak dalece rezygnacja z kierowania się własnym rozumem odziera nas z własnej autonomii i własnej osobowej godności.

\section{KONKLUZJA}

Czy ten proces pogłębiania irracjonalizmu jest nieodwracalny? Nie. Kiedy człowieka odziera się z jego godności, kiedy zmusza się go do życia w kłamstwie, wówczas budzi się w nim bunt. Przypomnijmy sobie jedno z ważnych haseł sprzed wyborów w 1989 roku: „Żeby Polska była Polską, $2+2$ musi być zawsze 4!" Dla obcokrajowców było to hasło dość zdumiewające. Ale myśmy pamiętali gorzki dowcip z „Podwieczorku przy mikrofonie”, kiedy na pytanie kierownika „Malinowski, ile jest $2+2$ ?”, ten odpowiedział „A ile Pan kierownik sobie życzy?" Tak się dalej żyć nie dało. Polacy w ogromnej masie zbuntowali się przeciw systemowi kłamstwa, który był zarazem bo być musiał - systemem przemocy. I dostrzegli to, że wyzwolenie z tego systemu musi rozpocząć się od szukania i mówienia prawdy. Najprostszej, najbardziej oczywistej, takiej właśnie, że $2+2$ musi być zawsze 4 . Doświadczyliśmy tego, że tylko poszukiwanie prawdy i kierowanie się nią uczyni nas wolnymi, przywróci nam człowieczeństwo. I tego udało się nam w zdumiewający sposób, bez rozlewu krwi, poprzez ruch i związek „Solidarność”, dokonać. Ale powrót do poszukiwania prawdy i życia w jej blasku, otwierającym nas na perspektywę dotarcia do Boga samego, nigdy nie jest ostateczny, wciąż trzeba go ponawiać. Choć więc encyklika Fides et ratio moim zdaniem nie przyniosła jak dotąd zbyt spektakularnych efektów, to jednak trzeba wracać do zawartych w niej idei, albowiem - jak mówią pierwsze jej słowa - „Wiara i rozum (Fides et ratio) są jak dwa skrzydła, na których duch ludzki unosi się ku kontemplacji prawdy". W tym nasza nadzieja, która oby nie umarła. 


\section{Summary \\ REASON ON THE DEFENSIVE. WITH REFERENCE TO FIDES ET RATIO}

This article refers to Fides et Ratio by John Paul II. Starting from the analysis of this letter, the author discusses the deficiency of ratio in three dimensions: philosophical, theological and social one.

Słowa kluczowe: Fides et ratio, Jan Paweł II, filozofia, teologia, dyskurs publiczny

Key words: Fides et ratio, John Paul II, philosophy, theology, public discourse

\section{Bibliografia}

B a u m a n Z., Nowoczesność i Zagłada, tłum. T. Kunz, Kraków 2009.

F 11 i p k o w s k i J., hasło „Modernizm” w: Encyklopedia katolicka, t. XVI, Lublin 2012.

F i 1 i p k o w s k i J., hasło „Postmodernizm” w: Encyklopedia katolicka, t. XVI, Lublin 2012.

He 11 e r M., Nowa fizyka i nowa teologia, Kraków 2014.

He 11 e r M., Sens życia i sens wszechświata. Studia z teologii współczesnej, Kraków 2014.

Ja n P a we $\nmid$ II, Encyklika Fides et ratio.

S z o s t e k A., Natura - rozum - wolność. Filozoficzna analiza twórczego rozumu we wspótczesnej teologii moralnej, Rzym 1990.

S z u b k a T., Filozofia analityczna. Koncepcje, metody, ograniczenia, Wrocław 2009, s. 230.

Tw a r d o w s k i K., O dostojeństwie uniwersytetu, Poznań 1933. 